\title{
CO-BRANDING CITRA PERTANIAN DAN DAYA TARIK AGROWISATA: STUDI KOMPARASI TAIWAN DAN INDONESIA
}

\author{
Nurina Rachmita \\ Mahasiswi Pascasarjana, Ilmu Geografi, Universitas Indonesia \\ Email:nrachmita@gmail.com \\ Raldi Hendro Koestoer \\ Dosen, Sekolah Ilmu Lingkungan, Universitas Indonesia \\ Email: ralkoest@yahoo.co.uk
}

\begin{abstract}
Indonesia is an agrarian country having rich in variety of natural and biological resources. With such capacity, Indonesia has a chance to develop agribusiness, as for in the area of agritourism. However, the problem is the farmers have a limitation to create agricultural activities for tourism. This study explains agritourism development in Indonesia with Taiwan agritourism-oriented. The method uses combine approach, i.e., literature and comparative studies, and analyze them with relevant theories. The result of this study found that agritourism management in Indonesia is still limited and has not been optimized. The conclusion of this study is that Taiwan case study can be applied to promote agritourism as for Indonesia, not even limited to the agriculture sector, but it can also be applied to the cultural sector.
\end{abstract}

Keywords: Agritourism, agriculture activities, tourism, marketing strategy, farm tourism

\section{Pendahuluan}

Wisata pertanian atau yang lebih dikenal dengan agrowisata mengalami peningkatan peminat dalam beberapa tahun belakangan ini, alasan pengunjung melakukan kegiatan agrowisata biasanya untuk mencari ketenangan, jauh dari hiruk pikuk perkotaan, menikmati udara yang sejuk dan keindahan alam. Selain untuk pariwisata, agrowisata dapat menyadarkan masyarakat sekitar akan pentingnya pelestarian sumber daya alam sehingga diharapkan akan terwujud pertanian yang berkelanjutan. 
Menurut Pasal 1 Peraturan Menteri Pariwisata No. 18 Tahun 2016 yang dimaksud Usaha Wisata Agro adalah usaha pemanfaatan dan pengembangan pertanian yang dapat berupa tanaman pangan dan hortikultura, perkebunan, perternakan, dan/atau perikanan darat untuk tujuan pariwisata. Clarke (1999) mengungkapkan bahwa ketika pariwisata memiliki hubungan langsung dengan lingkungan pertanian, maka hal tersebut dapat dikatakan pariwisata pertanian. Chang (2003) mendefinisikan bahwa wisata pertanian adalah sebuah pertanian yang menggabungkan produksi pertanian dan fungsi dari waktu luang, perjalanan, rekreasi, dan akomodasi dalam satu kesatuan. Dengan pariwisata yang berbasis pertanian memungkinkan wisatawan merasakan lingkungan pertanian dengan konteks pedesaan dan mereka dapat memahami lingkungan pedesaan dan kehidupan bertani (Di \& Miller, 2012).

Agar agrowisata dapat memberikan efek positif, dibutuhkan suatu strategi pemasaran yang baik. Salah satu kendala yang dihadapi petani untuk meningkatkan wisatawan adalah mereka tidak mengetahui dengan baik cara memasarkan dan mengidentifikasi hal-hal yang disukai wisatawan, serta tidak pandai mendesain pengalaman pariwisata yang memenuhi harapan wisatawan (Busby \& Rendle, 2000; Daugstad \& Kirchengast, 2013; Liang, 2017).

Salah satu negara yang memiliki peningkatan sektor pariwisata yang menonjol adalah Taiwan. Pada bulan Oktober 2018 Taiwan memiliki sekitar 300 perkebunan yang dikelola secara profesional sebagai destinasi wisata, baik lokal maupun asing (traveling.bisnis.com). Indonesia sebagai negara agraris memiliki potensi yang serupa dengan Taiwan, dimana kekayaan alam dan hayati yang beragam. Agrowisata pertanian padi di Indonesia relatif terbatas untuk digarap sementara usaha agribisnis sangat berpotensi. 
Berdasarkan permasalahan yang telah dikemukakan, tulisan ini membahas sekilas gambaran perkembangan agrowisata di Indonesia dengan orientasi agrowisata Taiwan. Fokus studi Liang et al, (2020) cenderung melakukan co-branding terhadap farm image (citra pertanian) dan aktivitas pertanian. Konsep ini akan menjadi referensi dalam penjabaran agrowisata di Indonesia.

\section{Metode}

Penulisan ini menggunakan metode penelitian studi literatur dan komparasi, serta menganalisis dengan basis teori yang relevan. Data yang digunakan pada kajian ini merupakan data sekunder, yang diperoleh melalui studi literatur, berita online, website, dokumen dan laporan dari lembaga terkait.

Dalam konteks analisis dilakukan analogi dan komparasi terhadap konsep basis yang merujuk pada co-branding dan wisata pertanian, dalam kaitan tersebut pandang ruang terhadap profil pertanian dan kegiatan yang berkaitan dengan pertanian menjadi fokus utama penjabaran bagi kepentingan agrowisata. Untuk kasus Indonesia, pemaparan yang mudah ditunjukan dapat dikemukakan pada tempat-tempat lumbung padi di Indonesia, yaitu di pulau Jawa. Sementara dengan pengulasan konsep agrowisata di Taiwan sebagian mengambil lokasi yang dikelola oleh Taiwan Taiwan Leisure Farms Development Association (TLFDA).

\section{Hasil dan Pembahasan}

Bagian ini akan menghantarkan profil agrowisata di Taiwan dan Indonesia. Pola wisata pertanian di Taiwan dikaitkan dengan proses pemeliharaan kehidupan pedesaan, termasuk brand image hingga pemasaran. Dalam konteks ulasan agrowisata Indonesia, para pengelola mengkaitkan proses pemasaran melalui berbagai akses media internet, baik langsung maupun tidak langsung. 


\section{Agrowisata di Taiwan}

Taiwan mulai mengembangkan agrowisatanya pada tahun 1988, dengan mendidik pemilik pertanian dalam mengelola pariwisata pertanian dan peternakan. Chang (2003) dalam penelitiannya mengemukakan alasan terbesar untuk mengembangkan wisata pertanian di Taiwan adalah untuk mengimbangi fluktuasi pendapatan pertanian. Ketika petani menghadapi penurunan hasil pertanian, mereka akan mempertimbangkan untuk meningkatkan pendapatan dari pekerjaan sampingan atau dengan diversifikasi pertanian. Masih di dalam penelitian yang sama, dari hasil analisisnya menyebutkan, terdapat enam faktor utama untuk strategi produksi, aktivitas dan layanan untuk mengembangkan wisata pertanian, diantaranya: sarana dan prasarana, pemeliharaan fasilitas dan kualitas layanan, kegiatan pertanian dengan karakteristik berbeda, pengalaman kehidupan pedesaan dan lingkungan alam, desain area berdasarkan fungsi yang berbeda dan kenyamanan.

Agrowisata di Taiwan sebagian besar dikembangkan oleh TLFDA, dikutip dari website resminya, TLFDA merupakan lembaga non-profit yang didirikan pada tahun 1998, organisasi ini bertujuan untuk mengembangkan potensi wisata pertanian dan daerah pedesaan di Taiwan. Lembaga ini menghubungkan akademisi, pemerintah dan industri bersama-sama mempromosikan pengembangan agrowisata di Taiwan. TLFDA memikul tanggung jawab yang terkait dengan pendidikan sosial dan perlindungan lingkungan, memastikan stabilitas dan keberlanjutan desa pertanian untuk menciptakan nilai sosial yang lebih besar. Berbagi pengetahuan kepada petani, menginspirasi untuk membentuk pertanian Taiwan menjadi pilihan gaya hidup. Dengan melakukan hal tersebut diharapkan para pemuda akan kembali ke desanya dan desa-desa terus melanjutkan budayanya. TLFDA juga berusaha menciptakan agrowisata yang ramah Muslim, untuk mendapatkan pengakuan dari wisatawan Muslim, pada tahun 2015 Biro Pariwisata Taiwan memberikan Sertifikat Restoran Muslim yang dikeluarkan oleh Chinese Muslim Association kepada restoran yang telah 
melalui program konseling dan standar audit yang ketat untuk pengembangan lingkungan restoran Muslim.

TLFDA membantu petani dengan mencari investor untuk mendirikan hotel dan restoran di daerah pertanian. Mereka memberikan pelatihan kepada petani untuk mengelola bisnis serta memasarkan pertanian dan produknya, sehingga petani dapat menjadi lebih mandiri (Padin, 2015). Asosiasi ini juga menjamin kebersihan agrowisata anggotanya, terutama untuk pertanian yang mengelola peternakan, hal ini dilakukan karena ketika wisatawan ingin berinteraksi dengan hewan di sebuah peternakan, wisatawan hanya ingin mengalami kegiatan yang bersih, mereka hanya ingin merasakan suasana pedesaan tetapi tidak benar-benar ingin merasakan lingkungan pedesaan yang sesungguhnya (Liang et al., 2020).

Dengan bank data yang dimilikinya, TLFDA dapat mengetahui waktu panen dan jenis varietas tanaman dari setiap anggotanya, sehingga TLFDA dapat membantu wisatawan dalam menentukan tujuan wisatanya. Setiap anggota agrowisata juga diwajibkan untuk memiliki satu hal yang menjadi ciri khas, bisa dari jenis tanaman yang ditanamnya atau menu makanannya.

Sebagai legalitas untuk kualitas layanan pertanian, pemerintah dan TLFDA membuat daftar trade-mark sejak tahun 2010. Ini digunakan untuk mengidentifikasi kualitas layanan agrowisata sehingga wisatawan dapat mengetahui dari sertifikatnya. Pertanian ini dievaluasi setiap tahun untuk mempertahankan trade-mark mereka (Min, Jennifer; Lin, Chien-Lin; Tang, 2018). 


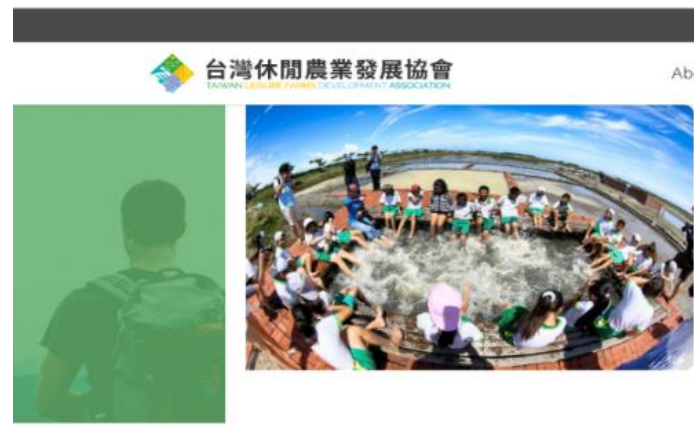

About Us / Certification / Tour Maps / Muslim / Fruits Travel

ABOUT US : The Taiwan Leisure Farms Development Association was founded in 1998
as a non-profit organization under the Civil Organizations Act. It aims to

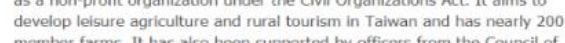
Agriculture under the Execotive Yupported by officers trom the Counc owners. Our mission is to bring the academia, the government, and the industry together for a better future of leisure agriculture and rural
tourism.

\section{More $\rightarrow$}

Gambar 1. Website Taiwan Leisure Farms Development Association.

(Sumber: $\underline{\text { https://www.taiwanfarm.org.tw/zh-EN/Front) }}$

Salah satu strategi pemasaran yang dilakukan Taiwan untuk meningkatkan kunjungan wisatawan pada sektor pariwisata pertanian adalah dengan melakukan cobranding antara citra pertanian dan pengalaman aktifitas pertanian. Definisi 'brand' menurut Kotler \& Keller (2009) adalah "nama, istilah, tanda, symbol, atau desain atau kombinasi dari semua yang telah disebutkan, yang dimaksudkan untuk mengidentifikasi barang dan layanan dari satu atau kelompok penjual untuk membedakan antara para pesaing". Sedangkan co-branding adalah dua atau lebih brand/merek yang bekerjasama untuk mencapai tujuan strategis masing-masing perusahaan (Denizci Guillet \& Tasci, 2012).

Citra pertanian mengacu pada kesan pertanian dalam pikiran pengunjung, hal ini dapat memberikan gambaran atau pengetahuan kepada pengunjung (Fakeye \& Crompton, 1991), terkadang dari citra pertanian ini pengunjung dapat menemukan hal yang unik dari suatu wisata pertanian. Contoh, pertanian dengan lingkungan liburan dan suasana santai, pertanian dengan lingkungan alami dan budaya ekologis, pertanian yang jauh dari kehidupan kota. Sedangkan aktivitas pertanian diantaranya memberi makan ternak, berinteraksi dengan hewan atau memetik buah dan sayuran (Liang et al., 2020). 
Cheng (2013) membagi aktifitas wisata pertanian menjadi lima kategori: (a) DIY (Do-It-Yourself), misalnya menyiapkan hidangan dari hasil memetik buah atau sayuran sendiri, membuat alat pertanian; (b) memberi makan hewan kecil, seperti kelinci dan anak sapi, (c) berinteraksi dengan hewan, misalnya memerah susu sapi, memasangkan pedati dengan hewannya; (d) penjelasan ekologi alami mengenai tumbuhan dan hewan/wisata ekologi; (e) memetik buah dan sayuran.

Liang et al., (2020) telah melakukan penelitiannya dengan menguji kecocokan dan hubungan antara citra pertanian dan pengalaman aktifitas pertanian berdasarkan perspektif co-branding, dua hal ini bersama-sama menciptakan pengalaman wisata pada wisata pertanian. Hasil analisis menunjukan bahwa ketika ada keserasian antara citra pertanian dan pengalaman aktifitas pertanian yang dilakukan wisatawan maka akan memberikan banyak pengalaman yang menyenangkan, dan aktifitas yang berbeda dapat digunakan untuk mengembangkan pertanian yang unik. Pada akhirnya hal ini dapat meningkatkan respon yang positif dari wisatawan, diantaranya wisatawan kemungkinan akan kembali untuk mengunjungi pertanian tersebut, memberikan rekomendasi pertanian tersebut kepada kerabat dan akan membeli cinderamata lebih banyak.

Agar wisatawan mengetahui citra pertanian dari suatu argowisata, maka citra pertanian harus dituangkan dalam suatu media dan disebarluaskan, salah satu media yang efektif untuk penyebaran informasi adalah media internet. Dengan internet wisatawan dapat mengetahui gambaran dari suatu agrowisata sebelum berkunjung. Karena gambar merupakan salah satu faktor terpenting ketika wisatawan memilih tujuan (Beerli \& Martín, 2004; Bigné et al., 2001; Castro et al., 2007). 


\section{Agrowisata di Indonesia}

Sama halnya dengan Taiwan, Indonesia memiliki Asosiasi Wisata Agro Indonesia (AWAI) yang didirikan pada tanggal 6 Maret 1999. Berdasarkan Keputusan Menteri Pertanian Nomor: 319/Kpts/KP.150/6/2003 Tentang Komisi Wisata Agro, AWAI merupakan anggota dari pelaksana harian Komisi Wisata Agro, yang mana tugas dari pelaksana harian diantaranya: (a) mempromosikan pengembangan Wisata Agro, (b) mengkoordinasikan pengembangan Objek Wisata Agro, (c) menyusun program kegiatan Komisi Wisata Agro, (d) melakukan evaluasi kegiatan yang telah dilakukan. Saat ini informasi yang tersedia adalah AWAI Jakarta, Jawa Tengah dan Jawa Timur.

Berdasarkan penelitian Liang et al., (2020) yang menganalisis hubungan antara citra pertanian dan aktifitas pertanian dengan perspektif co-branding, maka pada tulisan ini dilihat citra pertanian dan aktifitas pertanian dari beberapa agrowisata di Indonesia. Pemilihan agrowisata ditentukan pada wilayah pulau Jawa dan Bali. Pulau Jawa masih menjadi andalan pada sektor pertaniannya sebagai lumbung padi Indonesia, Pulau Bali merupakan sektor utama pariwisata Indoneisa. Agrowisata yang dipilih merupakan perwakilan dari kategori agrowisata sawah, sayur/buah, dan ternak (Gambar 2). Pengumpulan data melalui media internet, informasi dirangkum pada Tabel 1. Beberapa lokasi agrowisata masih terbatas dalam memberikan citra yang dapat ditampilkan melalui promosi website. 


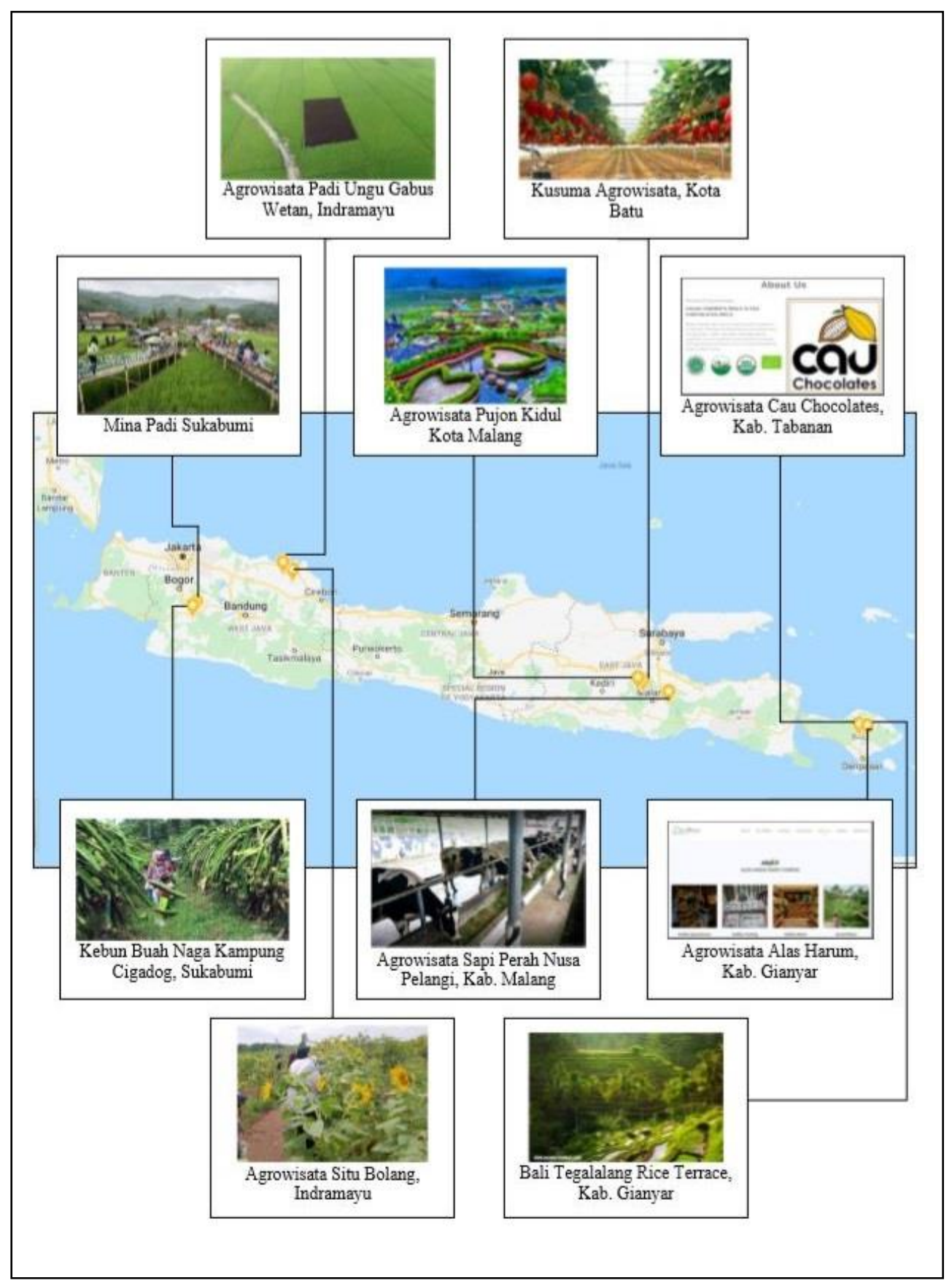

Gambar 2. Informasi Lokasi Sampel Agrowisata Indonesia

(Sumber: Diolah oleh Penulis, 2020)

Pada Tabel 1 dapat dilihat bahwa agrowisata pada wilayah yang tergolong maju sektor pariwisatanya, telah memiliki website dan menuliskan citra pertaniannya. Untuk aktifitas pertanian, sebagian besar agrowisata menyediakan lebih dari satu pengalaman aktifitas pertanian. 
Tabel 1. Hasil pengamatan beberapa sampel agrowisata di Pulau Jawa dan Bali,

Indonesia

\begin{tabular}{|c|c|c|c|c|c|}
\hline No & $\begin{array}{c}\text { Nama } \\
\text { Agrowisata }\end{array}$ & Lokasi & Kategori Aktifitas pertanian & $\begin{array}{c}\text { Citra } \\
\text { Pertanian }\end{array}$ & Sumber Data \\
\hline 1 & $\begin{array}{l}\text { Mina Padi } \\
\text { Sukabumi }\end{array}$ & $\begin{array}{l}\text { Kp. Cijuray Desa Cikurutug } \\
\text { Kec.Cirenghas Kab. } \\
\text { Sukabumi } \\
\text { Jawa barat }\end{array}$ & $\begin{array}{l}\text { Wisata ekologi } \\
\text { DIY (Do-It-Yourself) }\end{array}$ & Ada & $\begin{array}{l}\text { Facebook: } \\
\text { Minapadi } \\
\text { Sukabumi }\end{array}$ \\
\hline 2 & $\begin{array}{l}\text { Kebun Buah } \\
\text { Naga }\end{array}$ & $\begin{array}{l}\text { Kampung Cigadog, RT 04/05, } \\
\text { Desa Neglasari, Kec. } \\
\text { Nyalindung, Kab. Sukabumi, } \\
\text { Jawa Barat }\end{array}$ & $\begin{array}{l}\text { Wisata ekologi dengan } \\
\text { penjelasan } \\
\text { Memetik buah/sayur }\end{array}$ & - & $\begin{array}{l}\text { Travel.detik. } \\
\text { com }\end{array}$ \\
\hline 3 & $\begin{array}{l}\text { Agrowisata } \\
\text { Padi Ungu } \\
\text { Gabuswetan }\end{array}$ & $\begin{array}{l}\text { Blok Rong Desa Sekarmulya } \\
\text { Kec. Gabuswetan Kab. } \\
\text { Indramayu, Jawa Barat }\end{array}$ & Wisata ekologi & - & $\begin{array}{l}\text { Kumparan. } \\
\text { com }\end{array}$ \\
\hline 4 & $\begin{array}{l}\text { Agrowisata } \\
\text { SituBolang }\end{array}$ & $\begin{array}{l}\text { Jatisura, Cikedung, } \\
\text { Kab. Indramayu, Jawa Barat }\end{array}$ & $\begin{array}{l}\text { Memberi makan hewan } \\
\text { Wisata ekologi } \\
\text { Memetik buah/sayur } \\
\text { Permainan/DIY }\end{array}$ & - & TribunJabar.id \\
\hline 5 & $\begin{array}{l}\text { Agrowisata } \\
\text { Desa Pujon } \\
\text { Kidul }\end{array}$ & $\begin{array}{l}\text { Pujon Kidul, Pujon, Krajan, } \\
\text { Pujon Kidul, } \\
\text { Kec. Pujon, } \\
\text { Kota Malang, } \\
\text { Jawa Timur }\end{array}$ & $\begin{array}{l}\text { Memberi makan hewan } \\
\text { Wisata ekologi dengan } \\
\text { penjelasan } \\
\text { Berinteraksi dengan hewan } \\
\text { Memetik buah/sayur } \\
\text { Permainan/DIY }\end{array}$ & Ada & $\begin{array}{l}\text { sie.pujonkidul. } \\
\text { desa.id }\end{array}$ \\
\hline 6 & $\begin{array}{l}\text { Kusuma } \\
\text { Agrowisata }\end{array}$ & $\begin{array}{l}\text { Jl. Abdul Gani Atas No.12 } \\
\text { Ngaglik } \\
\text { Kec. Batu, Kota Batu, } \\
\text { Jawa Timur }\end{array}$ & $\begin{array}{l}\text { Memetik buah/sayur } \\
\text { Permainan/DIY }\end{array}$ & Ada & $\begin{array}{l}\text { kusuma-hotel. } \\
\text { com/facility/ } \\
\text { tampil/ } \\
\text { pickfruit }\end{array}$ \\
\hline 7 & $\begin{array}{l}\text { Sapi perah } \\
\text { Nusa } \\
\text { Pelangi }\end{array}$ & $\begin{array}{l}\text { Desa Wisata Gubugklakah } \\
\text { (DWG), Kecamatan } \\
\text { Poncokusumo, } \\
\text { Kab. Malang, Jawa Timur }\end{array}$ & $\begin{array}{l}\text { Wisata ekologi dengan } \\
\text { penjelasan } \\
\text { Berinteraksi dengan hewan } \\
\text { Memberi makan hewan }\end{array}$ & - & $\begin{array}{l}\text { nasirullahsitam. } \\
\text { com }\end{array}$ \\
\hline 8 & $\begin{array}{l}\text { Bali } \\
\text { Tegalalang } \\
\text { Rice Terrace }\end{array}$ & $\begin{array}{l}\text { Jl. Raya Tegallalang, } \\
\text { Tegallalang, Kec. Tegallalang, } \\
\text { Kab. Gianyar, Bali }\end{array}$ & $\begin{array}{l}\text { Wisata ekologi } \\
\text { Permainan/DIY }\end{array}$ & Ada & $\begin{array}{l}\text { baliriceterrac } \\
\text { e.com }\end{array}$ \\
\hline 9 & $\begin{array}{l}\text { Alas Harum } \\
\text { Agro } \\
\text { Tourism } \\
\text { Bali }\end{array}$ & $\begin{array}{l}\text { Jl. Raya Tegallalang, } \\
\text { Tegallalang, Kec. Tegallalang, } \\
\text { Kab. Gianyar, Bali }\end{array}$ & $\begin{array}{l}\text { Wisata ekologi } \\
\text { Permainan/DIY }\end{array}$ & Ada & alasharum.com \\
\hline 10 & $\begin{array}{l}\text { CAU } \\
\text { Chocolate }\end{array}$ & $\begin{array}{l}\text { Jl. Raya Marga-Apuan, Cau, } \\
\text { Marga, Kab. Tabanan, Bali }\end{array}$ & $\begin{array}{l}\text { Permainan/DIY } \\
\text { Memberi makan hewan } \\
\text { Wisata ekologi } \\
\text { Berinteraksi dengan hewan } \\
\text { Memetik buah/sayur }\end{array}$ & Ada & $\begin{array}{l}\text { cauchocolates } \\
\text { bali.com }\end{array}$ \\
\hline
\end{tabular}

(Sumber: Diolah oleh Penulis, 2020) 


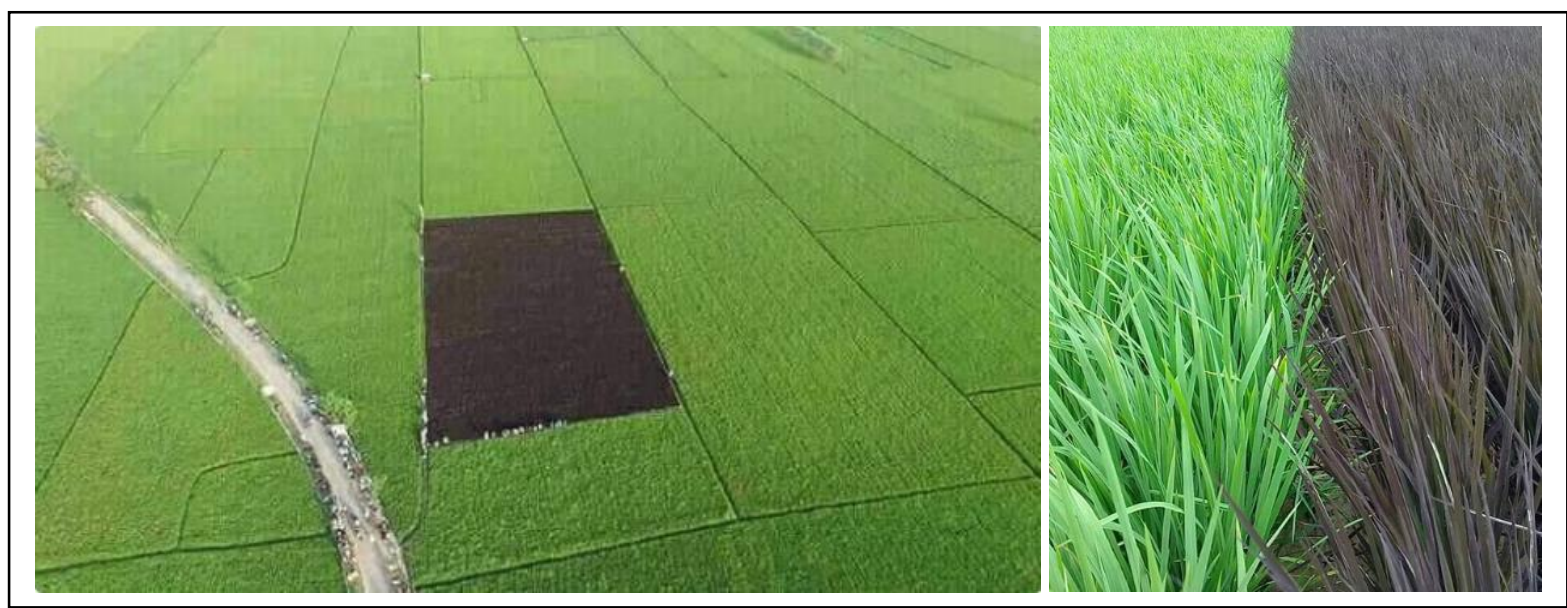

Gambar 3. Agrowisata Padi Ungu Gabus Wetan

(Sumber: https://www.kumparan.com)

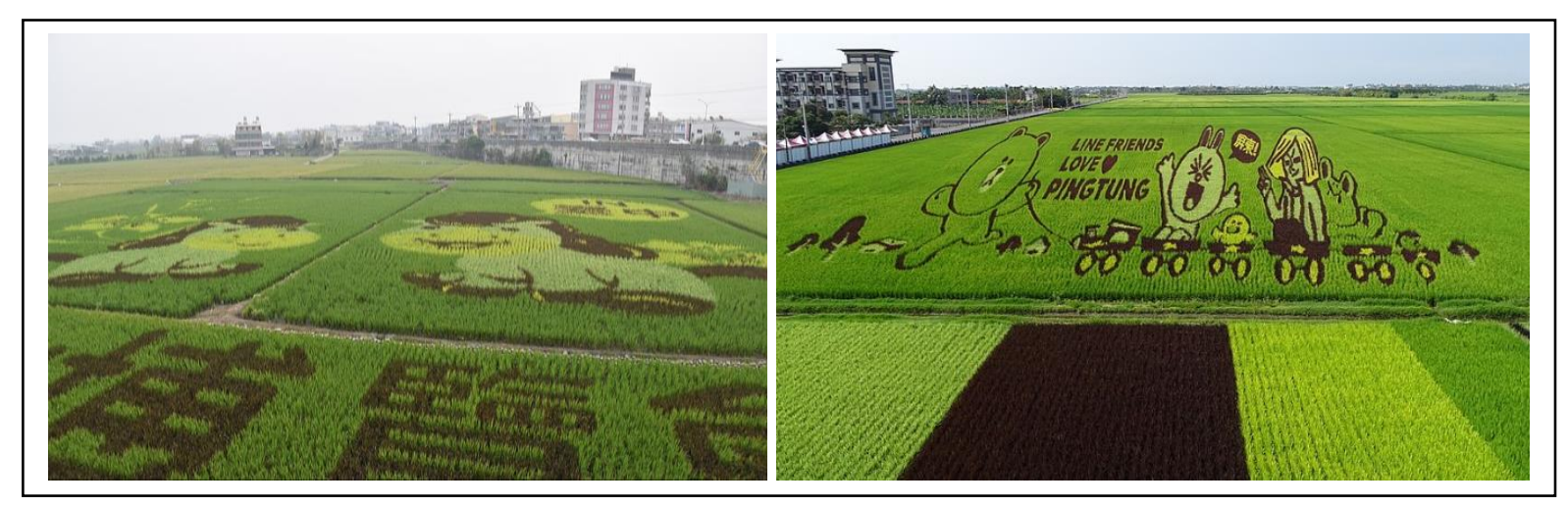

Gambar 4. Tanbo Art di Taiwan

(Sumber: https://commons.wikimedia.org/wiki/Category: Tanbo art in Taiwan)

Pada Agrowisata Padi Ungu Gabuswetan (Gambar 3) hanya terdapat satu aktivitas saja, hal ini dikarenakan agrowisata tersebut belum dikelola dengan baik oleh pemiliknya tetapi tempat tersebut sudah memiliki potensi untuk menjadi agrowisata yang maju, ini ditandai dengan antusias masyarakat yang datang ke tempat tersebut. Agrowisata Padi Ungu Gabuswetan adalah salah satu persawahan yang sebagian kecil sawahnya digunakan untuk menanam padi varietas Black Madras, masyarakat antusias untuk berfoto di persawahan tersebut karena keunikan pada warna daun padi yang berbeda, yaitu berwarna ungu. Varietas Black Madras 
sebenarnya belum dianjurkan oleh pemerintah, karena belum memiliki sertifikat izin edar dan bebas hama. Tetapi ternyata varietas ini berpotensi menjadikan hamparan sawah lebih menarik.

Dalam penggunaan varietas Black Madras, Taiwan mengikuti langkah Negeri Sakura menjadikan persawahan lebih menarik dengan metode Tanbo Art (Gambar 4), tanbo art adalah seni menanam padi dengan menggunakan warna padi yang berbeda. Dengan tanbo art, area sawah akan menjadi lebih menarik, sehingga masyarakat lebih antusias untuk mengunjungi area persawahan tersebut, bahkan di Jepang, yang merupakan negara asalnya, tanbo art dilakukan secara bersama-sama setelah area persawahan tersebut dibuat pola gambarnya. Tentunya hal tersebut menuntut kreatifitas dan inovasi dari pengelola pertanian dan masyarakat sekitar serta pendampingan dari pemerintah setempat.

Agrowisata Sapi Perah Nusa Pelangi merupakan hibah Dinas Peternakan dan Kesehatan Hewan Kabupaten Malang kepada Kelompok Ternak Sapi Perah Nusa Pelangi, Desa Gubugklakah, Kecamatan Poncokusumo, Kabupaten Malang. Ridwan et al. (2018) dalam penelitiannya menyatakan bahwa pengunjung terbanyak yang datang berasal dari Kabupaten Malang, hal ini kemungkinan disebabkan kurangnya promosi yang dilakukan oleh pengelola, promosi melalui media sosial terus dilakukan, namun kedatangan jumlah pengunjung masih belum sesuai harapan.

Agrowisata Desa Pujon Kidul di Kota Malang dan Agrowisata CAU Chocolate di Kabupaten Tabanan memiliki pengalaman aktivitas pertanian yang lebih beragam. Hal ini memiliki dampak pada perekonomian di sekitar agrowisata, karena dengan adanya agrowisata dan aktivitas pertanian di dalamnya, dapat terbentuk industri pariwisata. Industri pariwisata mempunyai sifat yang khas, tidak hanya melibatkan banyak industri, seperti transportasi, akomodasi, jasa boga, atraksi dan retail, industri 
pariwisata juga bersifat menyerap banyak tenaga kerja (Wardiyanta (2006) dalam (Arianti, 2014)).

Desa Pujon Kidul dibawah kepemimpinan Kepala Desanya telah berhasil meningkatkan Pendapatan Asli Desa (PADes) hingga lebih dari Rp 1,3 Miliar pada tahun 2018. Desa ini menjalankan program inovasi desa yang awalnya bertujuan untuk mensejahterakan para petani, namun ternyata program ini telah berdampak kepada sektor lainnya, hingga meningkatkan kesejahteraan masyarakat Desa (tribunnews.com, 2019). Desa Pujon Kidul menetapkan kebijakan, membuat inovasi, dan investasi dalam meningkatkan kesejahteraan masyarakatnya. Menetapkan kebijakan melalui kepala desa, membuat kreatifitas-kreatifitas hingga menghasilkan inovasi baru, dan menggunakan dana desa sebagai investasi untuk memajukan desa hingga terbangunlah sebuah agrowisata di desa tersebut. Agfianto et al. (2019) dalam penelitiannya menyatakan bahwa pengeluaran wisatawan pada Wisata Cafe Sawah yang berada di Desa Pujon Kidul telah memberikan dampak ekonomi langsung, tidak langsung dan lanjutan pada masyarakat di sekitar lokasi.

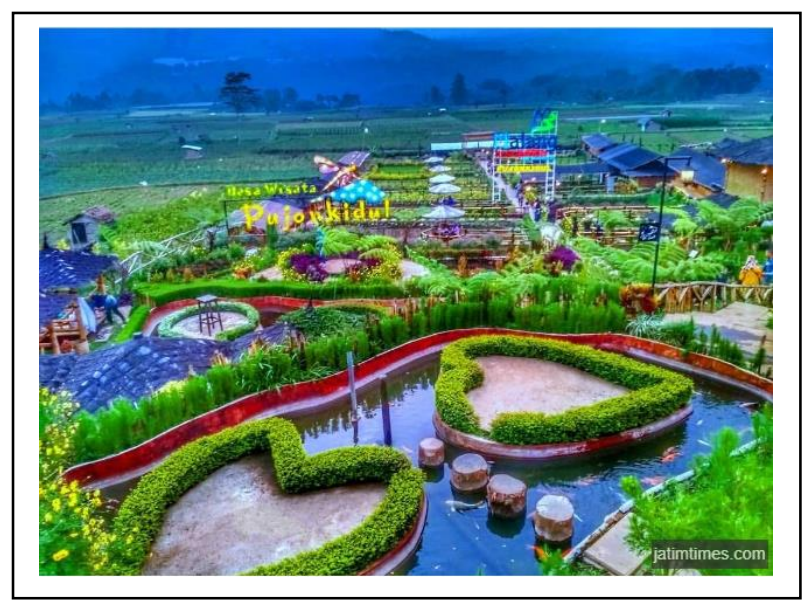

Gambar 5. Desa Wisata Pujon Kidul

(Sumber: https://rimbakita.com/desa-wisata-pujon-kidul/) 
Agrowisata CAU Chocolate cukup rinci menginformasikan profilnya di dalam website, diantaranya terdapat informasi mengenai citra pertanian, lokasi, produk yang dihasilkan, aktivitas pertanian, harga paket wisata dan beberapa sertifikat yang telah didapatkan. Dengan informasi yang diberikan, wisatawan dapat mengetahui gambaran dari suatu agrowisata sebelum berkunjung.

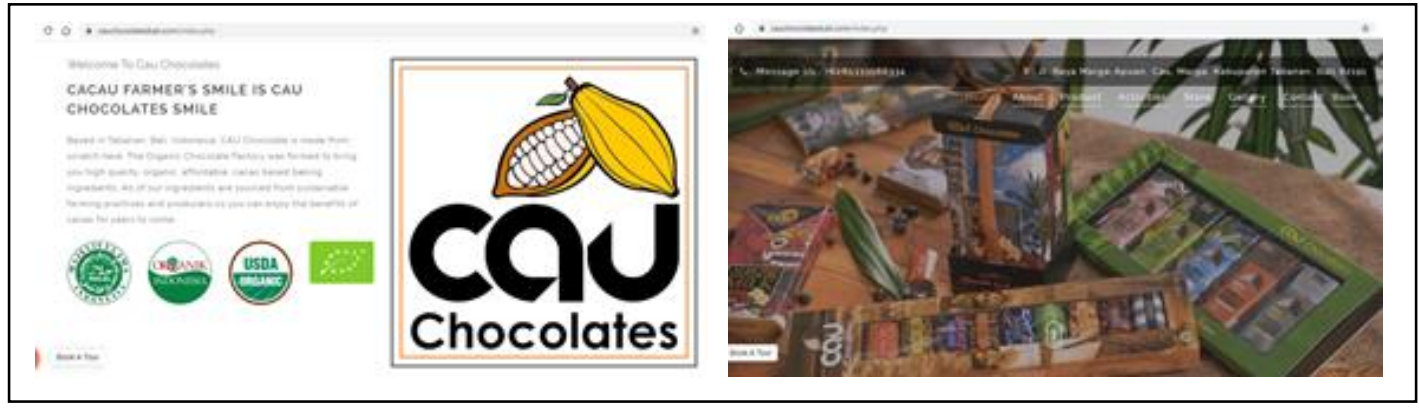

Gambar 6. Agrowisata CAU Chocolate

(Sumber: https://www.cauchocolatesbali.com/)

\section{Simpulan dan Saran}

Beberapa butir penting dari hasil pembahasan diatas dapat disimpulkan antara lain: pertama, ulasan kasus studi wisata di Taiwan dapat diterapkan terhadap promosi agrowisata di Indonesia, bahkan tidak terbatas pada sektor pertanian saja, tetapi bisa juga diterapkan pada sektor budaya. Kedua, potensi agrowisata di Taiwan dapat memberikan masukan terhadap agrowisata di Indonesia, hasil penelitian yang menyatakan bahwa agrowisata yang memiliki lebih banyak jenis kegiatan yang spesifik dan ada keserasian dengan citra pertanian maka akan lebih menarik wisatawan. Ketiga, distribusi spasial terhadap kegiatan pertanian cenderung memiliki daya tarik terhadap wisatawan dan ini dapat diterapkan di Indonesaia. Keempat, pengelolaan agrowisata di Indonesia masih relatif terbatas, sehingga belum memberikan kontribusi yang optimal. Kelima, promosi melalui mass media khususnya internet untuk menjangkau pemasaran yang lebih luas dapat memberikan pencerahan baru bagi potensi devisa negara. Terkait dengan hal tersebut agrowisata 
di Indonesia cenderung lebih banyak melakukan co-branding antar produk dibandingkan dengan citra pertanian. Keenam, AWAI sudah dibentuk namun masih banyak agrowisata yang belum menjadi anggotanya, padahal untuk meningkatkan perekonomian asosiasi ini dapat turut mempromosikan pentingngnya pelestarian sumber daya lingkungan, sehingga mendorong pola pertanian berkelanjutan.

Sebagai tambahan, penulis memberi masukan bagi pengembangan agrowisata Indonesia ke depan: pertama, dibutuhkan proses focus mapping potensi agrowisata di setiap kabupaten dan juga provinsi. Kedua, potensi-potensi sebaran agrowisata tersebut dikompilasi dalam satu website Dinas Pariwisata Provinsi dan Kabupaten. Dengan demikian wisatawan mancanegara lebih mudah mendapatkan informasi mengenai potensi agrowisata apabila ingin melakukan perjalanan ke Indonesia, sesuai dengan referensi lokasi yang dipilih.

\section{Ucapan Terima Kasih}

Penulis mengucapkan terima kasih kepada Kementerian Pendidikan dan Kebudayaan selaku pemberi Beasiswa Unggulan kepada penulis untuk menempuh studi S2 pada Program Studi Ilmu Geografi - Universitas Indonesia.

\section{Daftar Pustaka}

Agfianto, T., Antara, M., \& Suardana, I. W. (2019). Dampak Ekonomi Pengembangan Community Based Tourism Terhadap Masyarakat Lokal di Kabupaten Malang (Studi Kasus Destinasi Wisata Cafe Sawah Pujon Kidul). Jurnal Master Pariwisata (JUMPA), 05, 259.

Anonim. (2018, Februari). Padi Berwarna Ungu di Sawah Indramayu Jadi Tempat Favorit untuk Foto. KumparanNews. Diakses dari https://kumparan.com/kumparannews/padi-berwarna-ungu-di-sawahindramayu-jadi-tempat-favorit-untuk-foto/full. 
Anonim. (2019, Desember). Kunjungan Wisatawan Asing ke Taiwan Tembus 11.110.000 Orang. Taiwan Today Indonesia. Diakses dari https://id.taiwantoday.tw/news.php?unit=464\&post=167858\&unitname=Ekon omi\&postname=Kunjungan-Wisatawan-Asing-ke-Taiwan-Tembus11.110.000-Orang.

Anonim. Strategi pengembangan wisata agro di Indonesia. Direktori Wisata Argo Indonesia.

Diakses

dari http://database.pertanian.go.id/agrowisata/viewfitur.asp?id=1.

Alamsyah, Syahdan. (2019, Januari). Yuk, Agrowisata di Kebun Buah Naga di Sukabumi. Travel News. Diakses dari https://travel.detik.com/travel-news/d4402963/yuk-agrowisata-di-kebun-buah-naga-di-sukabumi.

Arianti, D. (2014). Pengaruh Sektor Pariwisata Terhadap Perekonomian dan Keruangan Kota Bukittinggi ( Pendekatan Analisis Input Output ). Jurnal Wilayah Dan Lingkungan, 2, 183-196.

Beerli, A., \& Martín, J. D. (2004). Factors influencing destination image. Annals of Tourism Research.

Bigné, J. E., Sánchez, M. I., \& Sánchez, J. (2001). Tourism image, evaluation variables and after purhase behaviour: Inter-relationship. Tourism Management.

Busby, G., \& Rendle, S. (2000). The transition from tourism on farms to farm tourism. Tourism Management, 21, 635-642.

Castro, C. B., Martín Armario, E., \& Martín Ruiz, D. (2007). The influence of market heterogeneity on the relationship between a destination's image and tourists' future behaviour. Tourism Management.

Chang, T. (2003). Development of Leisure Farms in Taiwan, and Perceptions of Visitors Thereto. Journal of Travel E Tourism Marketing, 15:1, 19-40.

Cheng, C.H. (2013). Exploring the Influence of leisure farm's experiential activities on the local consumption based on experiential education (No. 102AS-5.2.3-FS-\#1) Taipei. Executive Yuan, Taiwan: Council of Agriculture.

Clarke, J. (1999). Marketing structures for farm tourism: Beyond the individual provider of rural tourism. Journal of Sustainable Tourism.

Daugstad, K., \& Kirchengast, C. (2013). Authenticity and the pseudo-backstage of agritourism. Annals of Tourism Research.

Denizci Guillet, B., \& Tasci, A. D. a. (2012). Chinese hoteliers' take on hotel cobranding in China. Tourism Review, 67(4), 3-11. 
Di, M., \& Miller, G. (2012). Farming and tourism enterprise : Experiential authenticity in the diversi fi cation of independent small-scale family farming. Tourism Management, 33(2), 285-294.

Fakeye, P. C., \& Crompton, J. L. (1991). Image Differences between Prospective, FirstTime, and Repeat Visitors to the Lower Rio Grande Valley. Journal of Travel Research.

Herdiana, Dedi. (2019, Desember). Agrowisata Situ Bolang Indramayu Jadi Viral, Ada Ribuan Pohon Mangga Pengunjung Bisa Petik Langsung. Tribun Jabar.id. Diakses dari https://jabar.tribunnews.com/2019/12/29/argowisata-situ-bolangindramayu-jadi-viral-ada-ribuan-pohon-mangga-pengunjung-bisa-petiklangsung?page $=2$

Keputusan Menteri Pertanian Nomor : 319/Kpts/KP.150/6/2003 Tentang Komisi Wisata Agro. Kementerian Pertanian RI. Jakarta

Kotler, P., \& Keller, K. L. (2009). Marketing management (13th ed.). In Prentice Hall.

Liang, A. R. Da. (2017). Assessing the impact of co-branding of island destination and tourism activities on tourists' reactions. Current Issues in Tourism.

Liang, A. R. Da, Nie, Y. Y., Chen, D. J., \& Chen, P. J. (2020). Case studies on co-branding and farm tourism: Best match between farm image and experience activities. Journal of Hospitality and Tourism Management, 42(April 2019), 107-118.

Min, Jennifer; Lin, Chien-Lin; Tang, V. H.-W. (2018). EVALUATING SERVICE QUALITY OF LEISURE FARMS: THE TAIWAN CASE. The International Journal of Organizational Innovation, 11(July).

Padin, M. G. (2015, June 7). Taiwan hopes to attract more tourists via leisure farms. Business Mirror, June, 1-3.

Peraturan Menteri Pariwisata No. 18 Tahun 2016 Tentang Pendaftaran Usaha Pariwisata. Kementerian Pariwisata RI. Jakarta

Ridwan, A., Azizah, S., \& Eka Kusumastuti, A. (2018). Persepsi Pengunjung Terhadap Agrowisata Sapi Perah Nusa Pelangi Di Kabupaten Malang. Jurnal Master Pariwisata (JUMPA), 05, 57.

Sitam, Nasirullah. (2017). Agrowisata Sapi Perah di Desa Wisata Gubugklakah. Diakses dari https://www.nasirullahsitam.com/2017/08/agrowisata-sapiperah-di-desa-wisata-gubugklakah.html

Taiwan Leisure Farming Development Association (TLFDA). Taiwan farm. from http://www.taiwanfarm.org.tw/ 
Widianto, Danar. (2018, Januari). Pemerintah Tidak Rekomendasikan Petani Tanam Padi Ungu. Krjogja.com. Diakses dari https://www.krjogja.com/beritalokal/jateng/kedu/pemerintah-tidak-rekomendasikan-petani-tanam-padiungu/.

\section{Profil Penulis}

Nurina Rachmita, ST. adalah mahasiswi program magister Ilmu Geografi di Universitas Indonesia. Ia bekerja pada Bidang Budaya dan Bahasa unit Pusat Data dan Informasi Kementerian Pendidikan dan Kebudayaan, Jakarta sejak tahun 2014 hingga saat ini, dan bidang yang diminatinya adalah pengolahan data Point of Interest terutama yang terkait dengan data pendidikan, budaya dan objek wisata.

Raldi Hendro Koestoer, Ph.D. adalah Professor Ilmu Lingkungan Regional di Jakarta. Ia juga seorang dosen senior Perencanaan Tata Ruang dan Pembangunan Berkelanjutan di Sekolah Ilmu Lingkungan, Universitas Indonesia. Ia memperoleh gelar Ph.D dalam bidang Perencanaan Lingkungan dari Griffith University, Australia pada tahun 1992 dan minat penelitiannya pada Perencanaan dan Pengembangan Tata Ruang dan juga Isu berkelanjutan, terutama yang terkait dengan pembangunan di Indonesia dan Asia Tenggara. 